\title{
Gbaya Language
}

National Cancer Institute

\section{Source}

National Cancer Institute. Gbaya Language. NCI Thesaurus. Code C153928.

A family of languages spoken mainly in the Central African Republic, Cameroon, the Democratic Republic of the Congo, and the Republic of the Congo. 